\title{
PAHAM GENDER MELALUI MEDIA SOSIAL
}

\author{
Inda Marlina ${ }^{1}$
}

\begin{abstract}
Abstrak
Media sosial membuka peluang bagi kebebasan berpendapat, berbagi informasi, serta interaksi lintas ruang dan waktu. Sisi-sisi positif dari Media sosial ini dimanfaatkan oleh beberapa kelompok yang peduli terhadap penyebaran ilmu pengetahuan, salah satunya adalah pemahaman mengenai gender. Melalui media sosial, suatu berita dapat disebarluaskan secara cepat dan masif. Selain itu, pengetahuan mengenai pemahaman gender juga dapat diterima sedini mungkin. Beberapa gerakan di Indonesia yang telah terorganisasi mendirikan situs dan akun di media sosial. Gerakan tersebut antara lain Indonesia Feminis dan Laki-laki Baru. Di sisi lain, media digital yang fokus pada isu-isu gender, seksualitas, dan perbedaan juga muncul seperti Magdalene. Selain itu terdapat berbagai gerakan lain yang mengikuti perkembangan di dunia barat seperti Women March. Sejak dimulai pada 2017 di Jakarta, Women March, yang menarik aktivis dan penggiat feminisme, diadakan kembali pada 2018. Ajakan konvoi turun ke jalan untuk menyuarakan isu-isu gender dan seksualitas melalui Women March sudah merambah ke kota lain selain Jakarta seperti Pontianak, Serang, Salatiga, Bandung, Yogyakarta, Lampung, hingga Tondano. Dari hal ini, media sosial menjadi sarana penyebaran bersifat masif yang memicu adanya aksi langsung. Tulisan ini akan memuat mengenai peran-peran media sosial sebagai media penyebaran pemahaman gender, apa saja konten yang dimuat untuk memberikan pemahaman mengenai gender melalui ranah digital, dan aksi-aksi langsung seperti apa yang disertakan dalam pembelajaran mengenai gender tersebut.
\end{abstract}

Kata Kunci: media sosial, gender, pendidikan, feminisme, seksualitas, Women March, inklusi, perbedaan 


\section{Pendahuluan}

Sebelum penggunaan informasi teknologi (IT) meluas pada masa kini, terdapat perdebatan paham feminisme dalam menggunakan teknologi, terutama komputer. Perdebatan ini muncul dari dua tempat yang berbeda antara Amerika dan Jerman, di mana keduanya muncul pada tahun yang sama yaitu tahun 1997 (Everett, 2004). Dalam kurun waktu yang hampir bersamaan dengan munculnya gerakan tersebut di pertengahan era 1990an, internet pada saat itu tengah berkembang. Everett menuliskan bahwa antara tahun 1995-1997, terdapat banyak penulis perempuan yang produktif menghasilkan karya, seperti Third Wave Agenda: Being Feminist, Doing Feminism (1997) oleh Leslie Heywood dan Jennifer Drake (Everett, 2004: 1279).

Dua sisi feminisme dalam memandang teknologi ini terepresentasi dari cyberfeminism oleh First Cyberfeminist International (FCI) yang terbetuk di Kassel, Jerman dan cyberwomanism yang diwacanakan atas gerakan Million Woman March (MWM) di Philadelphia, Amerika Serikat. Meskipun keduanya bergerak dalam feminisme, akan tetapi keduanya memiliki pandangan berbeda terhadap media penyebaran gerakan mereka. Selain itu, pergerakan mereka juga tidak sejalur karena FCI didominasi oleh perempuan kulit putih dalam melawan supremasi patriarki melalui teknologi dan internet. Di sisi lain, penggerak MWM merupakan kelompok perempuan kulit hitam yang memperjuangkan suara warga kulit hitam, baik perempuan maupun laki-laki (Everett, 2004: 1280-1281). FCI dengan agenda cyberfeminsm-nya merupakan gerakan yang mempertanyakan keberpihakan teknologi terhadap feminisme. Wilding (1997) menuliskan bahwa FCI mempertimbangkan internet sebagai salah satu tempat untuk mengorganisir kerja-kerja feminisme melalui media di dunia maya. Di satu sisi, MWM secara tegas menunjukkan bahwa internet merupakan satu-satunya media yang dapat memberikan kebebasan pada mereka dalam menyebarkan berita maupun informasi mengenai perampasan hak-hak warga kulit hitam. Cyberfeminism memandang dunia maya merupakan suatu permasalahan, sedangkan cyberwomanism memandang dunia maya merupakan suatu solusi (Wilding, 1997 dalam Everett, 2004: 1280).

Fransesca Bray (2007) menyatakan teknologi menjadi salah satu alat konstruksi sosial pembagi gender. Teknologi cenderung dikonstruksikan untuk laki-laki, sedangkan perempuan dianggap tidak memahami cara kinerja dari teknologi sehingga hanya dapat menjalankan saja. Salah satu perbedaan penggunaan teknologi antara laki-laki dan perempuan adalah saat masa revolusi industri. Pada masa itu perempuan memang memegang mesin-mesin produksi di pabrik, 
akan tetapi mereka tidak diajarkan untuk memahami kinerja mesin tersebut dan hanya diajarkan bagaimana cara pengoperasian mesin tersebut secara permukaan untuk menjalankan produksi (Bray, 2007: 38).

Bray menuliskan pada tahun 1970an terdapat protes dari gerakan kaum feminis radikal dan kaum ecofeminist mengenai ketimpangan gender yang disebabkan oleh penggunaan teknologi. Protes tersebut menyebutkan ada dikotomi mengenai representasi teknologi modern yang disimbolkan laki-laki dan perempuan yang disimbolkan sebagai alam serta lingkungan. Dari hal ini studi mengenai feminisme teknologi atau feminist technology studies (FTS) berkembang. FTS merupakan paradigma dalam materialisme yang mengubah narasi patriarki teknologi menjadi netral di depan gender. Dengan kata lain, perempuan juga memiliki hak untuk mempelajari tekonologi seperti laki-laki. Dalam hal ini, saya melihat bahwa FTS telah berkembang hingga era digital (cyber) masa kini.

Beberapa tahun setelah perdebatan antara cyberfeminism dan cyberwomanism, Keller (2016) menuliskan melalui sudut pandang lain mengenai penggunaan internet bagi gerakan perempuan yaitu internet sebagai wadah di mana suara perempuan, terutama para remaja, dapat ditampung dan didengar. Riset yang diulas oleh Keller mengungkapkan bahwa remaja perempuan tidak memiliki ruang tersendiri untuk mengekspresikan dirinya. Suara-suara mereka tidak terdengar di ranah politik, misalnya dalam pemilihan umum, atau tidak terlihat pada saat ada aksi di balai kota (Keller, 2016: 261-262). Dunia maya menjadi suatu tempat perempuan lebih bebas dalam berpolitik tanpa perlu merasa termarginalisasi maupun merasa bahwa suaranya akan dibungkam. Keller menuliskan bahwa melalui media blog di internet, para remaja perempuan dapat berpartisipasi menyuarakan pendapatnya serta mengembangkan gerakan feminisme yang kontemporer (Keller, 2016: 261).

Pada beberapa literatur, kajian feminisme dan digital fokus pada identitas diri dan representasi identitas tersebut melalui internet dan media sosial (Genz dan Brabon, 2009 ; Dobson, 2015). Selain itu terdapat pula literatur yang seperti pandangan para cyberfeminism yang melihat bahwa ilmu pengetahuan dan teknologi merupakan ranah laki-laki (Wajcman, 1991). Tulisan ini mengetengahkan mengenai dinamika feminimisme dalam memanfaatkan media sosial untuk menyebarkan informasi secara cepat terutama dalam gerakan sosial dan fokus pada pembelajaran mengenai gender. Media sosial dianggap sebagai media yang mudah, murah, dan cepat sehingga efektif dalam 
menyebarkan informasi secara masif. Dari pengamatan yang saya lakukan, penggunaan media sosial saat ini tidak lagi sebagai pengenalan diri tetapi juga telah menjadi ajang penyebaran ideologi hingga politik. Dalam tulisan ini, saya akan fokus pada penggunaan media sosial sebagai salah satu cara untuk "belajar" dan mendapatkan informasi mengenai gender serta isu-isu yang melingkupinya seperti feminisme, seksualitas, hingga maskulinitas.

\section{Seperempat Hari Untuk Internet:}

\section{Akankah Bertambah?}

Saya teringat lagu rap dari penyayi Saykoji berjudul "Online" ketika menuliskan artikel ini. Lirik lagu itu menyebutkan bahwa kita melakukan kegiatan online atau menggunakan internet mulai dari bangun tidur hingga menjelang tidur, baik itu menggunakan telepon pintar atau komputer lipat. Perilaku yang bergantung dengan internet mulai dari mencari alamat seseorang, memesan makanan walau restorannya hanya berjarak empat gang dari rumah, membeli parfum edisi terbatas dari desainer ternama di Amerika Serikat, hingga memesan tiket pesawat untuk liburan tahun depan dapat dilakukan secara bersamaan. Selain itu, media sosial yang terhubung langsung oleh internet juga telah menjadi rutinitas sebagian besar komunitas. Media sosial tidak hanya memuat mengenai profil diri seseorang tetapi juga menjadi salah satu media yang digunakan untuk penyebaran berita dari suatu instansi (baik koran maupun bukan).

Berita dan informasi datang silih berganti tanpa jeda waktu. Terutama apabila berita tersebut sedang hangat dibicarakan oleh publik. Berita atau informasi, meskipun kebenarannya dipertanyakan, dapat menyebar dengan masif - sangat cepat dan menyebar luas layaknya virus- atau disebut sebagai viral di internet. Apabila suatu berita telah menyebar secara viral, maka akan sulit untuk membendung berbagai macam pendapat maupun versi lain dari berita tersebut.

Perusahaan media digital dari Inggris, We are Social, bekerja sama dengan perusahaan manajemen media sosial Hootsuite mengadakan penelitian mengenai penggunaan internet hingga bulan Januari tahun 2018 ini. Data mengenai konsumsi internet oleh masyarakat ini dapat menunjukkan seberapa masif suatu informasi akan disebarkan melalui internet. We are Social membeberkan data statistika mengenai penggunaan internet secara global maupun di setiap benua yang teridiri dari 239 negara. Secara keseluruhan dari penelitian tersebut setidaknya ada empat milyar orang yang mengakses internet hingga bulan Januari tahun 2018 dari total populasi dunia sekitar 7,6 milyar pada tahun yang sama. Data tersebut menunjukkan bahwa setidaknya 3,2 milyar orang merupakan pengguna media sosial yang 
aktif. Tiga milyar di antaranya menggunakan telepon pintar mereka dalam mengakses internet dan media sosial.

Data yang dihimpun dari We are Social dan Hootsuite tersebut menunjukkan bahwa terjadi peningkatan dari penggunaan internet di seluruh dunia. Peningkatan penggunaan internet tersebut rata-rata 7 persen sejak bulan Januari 2017. Riset ini juga mencatat bahwa setidaknya 55persen dari jumlah penduduk di Asia Tenggara merupakan pengguna media sosial.

We are Social dan Hootsuite menunjukkan bahwa Facebook masih mendominasi media sosial yang banyak diakses di seluruh dunia. Data tersebut dihimpul dari pengguna media sosial yang aktif dari awal 2017 hingga 27 Januari 2018 yang lalu. Media sosial buatan Mark Zuckerberg pada tahun 2004 itu diakses oleh 2,2 milyar orang. Di bawah Facebook, terdapat platform media sosial lain seperti Youtube, WhatsApp, FB Messenger, hingga Kakaotalk. Instargam yang juga merupakan anak perusahaan dari Facebook menempati urutan ke tujuh. Sekitar 800 juta akun terdaftar aktif menggunakan media sosial ini. Di sisi lain, Twitter berada di urutan ke sebelas dalam penggunaan media sosial di seluruh dunia.

Riset media sosial ini juga mengungkapkan konsumsi media sosial yang ada di masing-masing negara dari 239 negara yang ditelitinya. Fokus pada Indonesia, We are Social dan Hootsuite mencatat bahwa penggunaan media sosial di Nusantara melalui telepon pintar meningkat sekitar 30persen setiap tahun atau kurang lebih 28 juta pengguna sejak awal bulan Januari 2017. Pengguna media sosial yang aktif juga mengalami peningkatan hingga 23 persen atau sekitar 24 juta pengguna. Dari 265,4 juta total penduduk di Indonesia, 60 persen menggunakan telepon pintar. Ratarata orang Indonesia mengakses internet setiap hari dengan menggunakan media apapun (baik komputer, komputer lipat, maupun telepon pintar) menurut riset ini adalah 8 jam 51 menit. Untuk konsumsi media sosial, rata-rata orang akan menghabiskan waktu sekitar 3 jam 23 menit di layar telepon pintar, komputer, atau komputer lipat mereka. 124,8 juta pengguna internet menggunakan telepon pintar mereka untuk mengakses internet. Hal ini juga diperkuat data bahwa satu orang dalam sehari kemungkinan peluang menggunakan internet dipastikan sebanyak 79 persen.

We are Soscial dan Hootsuite mencatat bahwa media sosial yang sering di Indonesia bukanlah Facebook, melainkan Youtube. Platform media sosial yang menampilkan video tersebut diakses oleh setidaknya 43 persen pengguna media sosial aktif di Nusantara. Di susul kemudian di bawahnya adalah Facebook yang menempati 
urutan kedua atau sekitar 41 persen dari pengguna internet, kemudian WhatsApp, Instagram, dan Line di urutan ke lima. Penelitian ini menyoroti dua media sosial yang masih berada dalam satu perusahaan yaitu Facebook dan Instagram yang digunakan di Indonesia. Kedua platform ini menujukkan bahwa pengguna Facebook 50 persen mendata diri sebagai laki-laki, begitu pula dengan 51 persen pengguna Instagram. Dari rentang usia, 11 juta pengguna media sosial jenis apapun berada di usia 13-17 tahun. Usia terbanyak yang menggunakan media sosial adalah rentang usia antara 1824 tahun dengan jumlah rata-rata sebanyak 22 juta pengguna.

Kelanjutan dari riset yang dilakukan untuk Indonesia tersebut adalah melihat statistika perilaku dari pengguna teknologi. Dari data yang dihimpun selama 30 hari terakhir penggunaan internet di Indonesia (dimulai pada 27 Desember 2017), sekitar 44 persen pengguna internet menghapersenbiskan waktunya untuk mengunggah foto dan video. Budaya membaca seperti membaca buku elektronik atau majalah elektronik hanya sebanyak 3 persen. Data tersebut menunjukkan bahwa pengguna internet di Indonesia lebih memilih membaca berita cepat (flash news) karena data menunjukkan sekitar 18 persen pengguna memanfaatkan internet untuk membaca berita cepat. Selain itu, belanja melalui internet juga lebih tinggi persentasenya dibandingkan membaca yaitu 4 persen pengguna akan melakukan belanja online.

Dari data tentang memanfaatkan media sosial di atas, terdapat beberapa pendapat mengenai perilaku bermedia sosial di Indonesia. Kementerian Komunikasi dan Informatika merilis berita bahwa akan sangat disayangkan apabila pengguna media sosial di Indonesia yang sangat aktif terhadap internet hanya memanfaatkan internet untuk mengunggah status atau hanya saling berkirim komentar melalui paltform tersebut. Pada 2013, Kemenkominfo telah mencatat bahwa Indonesia menjadi negara yang menempati peringkat ke empat dalam penggunaan Facebook dan peringkat ke lima dalam penggunaan Twitter.

We are Social dan Hootsuite menyartakan setidaknya 71 persen dari orang-orang yang menggunakan internet percaya bahwa teknologi menawarkan banyak kesempatan. Berkaitan dengan kepercayaan masyarakat Indonesia terhadap tekonologi yang menawarkan banyak kesempatan, lembaga penelitian lain seperti Statista meneliti mengenai perkembangan belanja melalui media dalam jaringan. Mengutip dari Statista yang ditulis oleh media Tirto melalui tirto.id, pada 2017 penjualan ritel global melalui sistem online meningkat sekitar 10,1 persen. Tirto juga menuliskan dari hasil survei TEMASEK dan 
Google bahwa nilai pasar dari perdagangan digital ini akan mencapai $\$ 81$ miliar pada tahun 2025. Dengan demikian dapat disimpulkan bahwa pedagang digital di internet akan semakin bertambah banyak dalam kurun waktu tujuh hingga delapan tahun ini.

\section{Sosial Media: Sarana Pemicu Gerakan} Sosial

\section{a. Mengumpulkan Informasi Tentang} Gender Melalui Media Sosial

Arus informasi dari media sosial tidak memiliki keterbatasan. Dari perkembangannya saat ini, terdapat berbagai komunitas serta organisasi baik nongovernmental organization hingga lembaga pemerintah yang memiliki media sosial. Komunitas yang memiliki media sosial memiliki blog mereka dengan berita berkaitan dengan gerakan yang mereka usung. Dalam tulisan ini saya akan menyoroti Indonesia Feminis dan Laki-laki Baru yang konsisten memberikan informasi mengenai kesetaraan gender melalui media sosial.

Indonesia Feminis merupakan platform media yang membahas tentang isu-isu feminisme, terutama di Indonesia. Media ini bergerak melalui media sosial yaitu Facebook, Instagram, dan Twitter. Indonesia Feminis memiliki acara tetap bertajuk Heart to Pussy Talk setiap hari Rabu pukul 20.00 dan dialog dengan berbagai topik dengan narasumber bertajuk Mbok Femi yang disiarkan ulang melalui saluran You Tube mereka. Kedua tayangan bincang-bincang yang mereka adakan secara langsung tersebut membahas berbagai permasalahan yang tengah hangat dibicarakan misalnya mengenai catcalling atau godaan yang ada ranah publik sebagai suatu bentuk pelecehan atau mengenai seputar mitos keperawanan.

Indonesia Feminis memiliki jejaring sesama komunitas feminisme seperti komunitas Cherbon Feminist dari daerah Cirebon, Jawa Barat. Pada bulan Ramadhan tahun 2018 lalu, kedua komunitas tersebut mengadakan acara bincang-bincang yang disiarkan secara langsung yaitu Ngaji Feminis. Dalam acara tersebut, fokus utama pembahasan adalam mengenai paradigma feminisme yang berada di dalam ranah Islam.

Selain mengadakan acara langsung secara online, sebagai portal media sosial Indonesia Feminis menyalurkan kegiatankegiatan yang berkaitan dengan feminisme seperti gender, seksualitas, dan hak asasi manusia terutama perempuan dan anak. Acara tersebut antara lain Setengah Hari Belajar Gender, Feminisme dan Lingkungan, dan Feminsme dan Reformasi. Berjejaring merupakan salah satu ciri gerakan sosial. Membentuk jaringan merupakan suatu strategi para penggerak isu untuk mengajak 
orang lain melihat permasalahan yang mereka usung (Porta dan Diani, 2006). Informasi yang diberikan oleh platform media ini dimanfaatkan sebagai informasi awal mengenai feminisme, terutama isu-isu yang berkaitan dengan gender.

Dalam mini riset yang saya lakukan untuk menggali mengenai pembelajaran gender melalui media sosial, saya mewawancarai secara mendalam dua orang dengan latar belakang pendidikan berbeda tetapi memiliki jenjang yang sama. Informan pertama saya bernama Tia merupakan seorang perempuan lulusan Jurusan Pariwisata Universitas Gadjah Mada pada pertengahan tahun 2017 lalu. Dia mengatakan platform Indonesia Feminis sangat membantunya memahami mengenai kesetaraan gender. Selain itu, dia juga terbantu secara akademis karena Indonesia Feminis menjadi gerbang pembuka untuk menuliskan skripsi yang bertemakan pemberdayaan perempuan. Tia awalnya mengenal Indonesia Feminis melalui Twitter sekitar pertengah tahun 2016 saat sedang mencari bahan skripsi. Temannya yang meretweet salah satu berita dari akun Indonesia Feminis di Twitter. Karena tertarik dengan pembahasan mengenai pernikahan dini yang diunggah temannya tersebut, Tia kemudian mengikuti Twitter dan Instagaram Indonesia Feminis.

Dalam belajar mengenai feminisme, terutama kesetaraan gender, Tia tidak mendapatkan pendidikan formal mengenai gender di kuliahnya. Pelajaran mengenai gender baru diberikan di jurusan tempat dia belajar pada angkatan di bawahnya. Akan tetapi, karena tertarik dengan isu-isu kesetaraan gender, Tia memberanikan diri menyusun skripsi mengenai pemberdayaan perempuan di desa wisata.

Kesetaraan gender bagi Tia awalnya hal yang baru. Di lingkungan rumahnya, dia memang tidak dilarang untuk bekerja. Akan tetapi, orang tuanya mengajarkan bahwa urusan di dapur seperti memasak atau cuci piring tetap menjadi tugas utama perempuan. Dengan mengetahui informasi mengenai kesetaraan gender, Tia menyadari bahwa ranah domestik tidak hanya menjadi tanggung jawab perempuan tetapi juga tanggung jawab laki-laki.

Informasi, bahasan, dan tautan berita yang diunggah oleh Indonesia Feminis membantunya dalam menelusuri lebih lanjut apa yang dimaksud dengan kesetaraan dan pembagian beban pekerjaan antara laki-laki dan perempuan. Tia mengatakan membaca portal seperti Indonesia Feminis dan Magdalene membuat dirinya semakin berpikiran terbuka, terutama pada isu mengenai perempuan.

"Membaca mengenai berita atau informasi dari dua media tersebut (Indonesia Feminis dan Magdalene) membuat saya memahami bahwa perbedaan kerja antara laki-laki dan perempuan di ranah publik dan 
domestik itu merupakan konstruksi sosial" (Wawancara dengan Tia, 9 Juni 2018).

Tia mengatakan bahwa platform dan portal berita seperti Indonesia Feminis dan Magdalene merupakan salah satu akun media sosial yang berguna serta efektif dalam mempelajari mengenai gender. Meski demikian, terdapat pula bahasan yang dia tidak setuju seperti unggahan dengan bahasa yang memaksa dan terkesan menyalahkan orang lain. Tia menyadari bahwa tidak semua unggahan di Indonesia Feminis akan senada dengan pendapatnya. Dalam hal ini, dia tidak enggan menyaring informasi yang masuk.

"Masih banyak unggahan di Indonesia Feminis atau Magdalene yang bermanfaat untuk dibaca. Saya memang tidak bisa mengendalikan apa yang mereka unggah, tetapi saya dapat mengendalikan apa yang akan saya baca dan terima" imbuhnya.

Memahami konteks dan teks dari media sosial merupakan salah satu keterampilan utama dalam literasi digital. Livingstone menyatakan bahwa literasi tidak hanya keterampilan membaca dan menulis akan tetapi juga keterampilan untuk memahami (Livingstone, 2008: 106 dalam McPherson dkk, 2001). Livingstone menambahkan bahwa memahami literasi dunia digital seperti yang dilakukan oleh Tia bertujuan untuk tiga hal yang dapat berkontribusi pada masyarakat. Pertama, adanya partisipasi dalam demokrasi. Tia juga tidak menerima secara mentah-mentah informasi yang didapat di kedua platform media sosial yang diikutinya. Dia memiliki pengetahuan untuk memilih apa yang masih relevan dengan kapasitasnya sebagai mahasiswa. Literasi dalam media sosial merupakan pembelajaran jangka panjang, ekspresi kebudayaan, serta kebebasan berpikir yang dapat diterapkan di di dalam kehidupan sehari-hari. Livingstone menambahkan bahwa literasi digital juga "contribute to the critical and expressive skills that support a full and meaningful life and to an informed creative and ethical society" (Livingstone, 2008: 114 dalam McPherson, dkk, 2001).

Selain Indonesia Feminis, platform media sosial yang menyebarkan informasi mengenai kesetaraan gender adalah Lakilaki Baru. Apabila Indonesia Feminis melihat kesetaraan gender dari kacamata perempuan, Laki-laki Baru mengajak kaum laki-laki untuk melihat suatu permasalahan dari paradigma feminisme dan kesetaraan gender. Selain media sosial, Laki-laki Baru memiliki situs blog sendiri yang berisi artikel dengan isu-isu feminisme dan kesetaraan gender. Tulisan-tulisan di dalam situs tersebut antara lain tulisan dari Zuhdan Ari Sandi berjudul "Pelecehan Seksual Itu Ada dan Nyata!" (https://lakilakibaru.or.id/pelecehan-seksualitu-ada-dan-nyata/) dan tulisan Diar Ruly 
Januari yang menuliskan mengenai pembagain peran di dalam keluarga Islam "Umar Badrun Islam: Berbagi Peran Domestik adalah Tanggung Jawab Keluarga" (https://lakilakibaru.or.id/umarbadrun-islam-berbagi-peran-domestikadalah-tanggung-jawab-keluarga/). Laki-laki Baru juga rutin mengadakan kelas terbuka untuk laki-laki maupun perempuan seperti Forum Belajar: Laki-laki Sebagai Caregiver untuk Korban Kekerasan Seksual, mengisi kegiatan IGLOW: Generasi Muda Indonesia yang Saling Menghormati, diskusi dengan tajuk "Feminism for Men", dan obrolan dengan tema "Menjadi Ayah untuk Anak Perempuan".

Literatur mengenai teori laki-laki yang menggunakan paradigma feminis belum terlalu banyak disorot. Genz dan Brabon (2009) memang menuliskan mengenai laki-laki dan feminisme. Akan tetapi, posisi laki-laki yang ada di dalam tulisan tersebut cenderung mengarah pada laki-laki urban metroseksual, bukan sebuah gerakan mengenai paradigma feminisme. Dalam hal ini, Laki-laki Baru tidak menjadi sebuah platform media sosial yang menawarkan mengenai hal-hal metroseksual, akan tetapi mengajak agar laki-laki melihat permasalahan kesetaraan gender dari sudut pandang perempuan serta jauh dari patriarki.

Informan kedua adalah Adlun, seorang mahasiswa jurusan Antropologi Sosial Universitas Khairun Ternate yang juga mengetahui platform berita Indonesia Feminis dan Laki-laki Baru. Dia mengikuti akun Instagram Indonesia Feminis karena memiliki paham yang sama dengan gerakan tersebut. Adlun merupakan aktivis mahasiswa dan mempelajari mengenai gender. Dia juga aktif dalam diskusi gerakan perempuan di Ternate serta aktif dalam beberapa kegiatan langsung gerakan perempuan. Salah satu gerakan langung yang dia ikuti adalah mengikuti Women's March di Ternate.

Laki-laki yang duduk di semester ke empat ini mengatakan media sosial diperlukan untuk menyuarakan ketimpangan seperti kekerasan berbasis gender, kekerasan seksual, atau seksisme. Melalui media ini, informasi yang melingkupi berita atau di mana mencari tempat perlindungan maupun lembaga bantuan hukum akan mudah ditemukan. Selama mengikuti media sosial Indonesia Feminis, dia memanfaatkan bahasan terkini mengenai kampanye, informasi, dan diskusi terkait dengan feminisme. Adlun juga mengikuti kontenkonten yang berkaitan dengan hak-hak perempuan dan hak asasi manusia serta perlindungan terhadap perempuan dan anak.

Sama seperti Tia, pemahaman mengenai kesetaraan gender tidak didperoleh Adlun melalui bangku kuliah, akan tetapi melalui diskusi-diskusi di luar jam kuliah dan membaca. Dia berpendapat bahwa platform media sosial seperti Indonesia Feminis atau 
Laki-laki Baru merupakan salah satu pemantik awal dalam mengenal kesetaraan gender, tetapi tidak dapat digunakan sebagai landasan dasar pemahaman mengenai gender maupun paradigma feminisne.

"Media sosial seperti Indonesia Feminis memang awalan yang bagus dalam memantik orang mencari tahu (isu gender), akan tetapi harus dibutuhkan diskusi dan literasi yang panjang agar paham mengenai paradigma feminisme" ujarnya (wawancara dengan Adlun, 10 Juni 2018).

Perkembangan media sosial saat ini tidak hanya menjadi tempat untuk bertukar informasi diri, tetapi juga mendapatkan ilmu pengetahuan. Perkembangan internet ketika memasuki abad ke 21 atau selama kurang lebih satu dekade ini, menunjukkan perubahan signifikan terhadap internet. Stivens (2007) menuliskan bahwa media sosial menjadi wadah kosmopolitanisme yaitu merupakan salah satu kunci dalam pergerakan sosial berdasarkan pemahaman gender (Stivens, 2007: 87). Stiven menuliskan,

"One feminist attempt to deal with the postmodern and postcolonial deconstructions of universalising feminisms was a reassertion (and perhaps reinvention) of women's rights as human rights" (Stivens, 2007: 93).

Seperti yang dituliskan Stiven di atas, feminis yang berada di era postmodern menjadi repetisi dari permasalahan feminisme mulai dari gelombang pertama di mana perempuan masih mecari tempat dalam panggung politik hingga era postfeminist saat ini. Dalam era media sosial, sikap terhadap kesetaraan gender mempertegas sikap politis seseorang. Judith Butler telah menyebutkan bahwa suatu hal yang mustahil apabila memisahkan antara gender dengan politik dan kebudayaan, di mana kedua hal tersebut menopang keberadaan kesetaraan satu sama lain (Butler, 1990: 5).

Teknologi digital memberikan kesempatan untuk mempertegas arah kesetaraan gender masa kini. Dalam media digital, penyedia media dan audiens memiliki posisi kuasa yang setara sehingga tercipta ruang yang interaktif (McPherson, $\mathrm{dkk}$, 2008). Untuk menunjang pemahaman memanfaat teknologi digital diperlukan literasi media digital yang baik. Media sosial memberikan pemahaman kesetaraan gender dengan cara yang sederhana dan dekat dengan kehidupan sehari-hari.

\section{Kekuatan Tanda Pagar dan Representasi} Gelombang Feminisme Saat Ini

Gender dan feminisme merupakan dua topik pembahasan yang tidak dapat dipisahkan karena terkait satu sama lain. Dalam mempelajari gender, paradigma feminisme akan selalu hadir. Aksi langsung 
dalam membela kesetaraan gender pada masa kini salah satunya dipicu oleh gerakan melalui media sosial. Twitter merupakan salah satu media sosial yang banyak mempengaruhi berbagai aksi langsung tersebut. Penggunaan hashtag (\#) atau tandapagar (tagar) untuk kata kunci suatu isu tidak disangka menjadi perubahan yang dinamis dalam menyuarakan suatu hal. Beberapa tagar yang berkaitan dengan isu hak asasi manusia dan kesetaraan gender menjadi viral di internet, bahkan tidak hanya di Twitter saja tetapi di platform media sosial yang lain. Sebagai salah satu bentuk kampanye, tagar digunakan oleh siapa saja termasuk para pesohor, politikus, hingga pemuka agama.

Media BBC dan Globalcitizen menuliskan mengenai beberapa tagar yang digunakan untuk menggerakkan masa secara masif dalam melakukan kampanye global. Dari tagar-tagar yang disebutkan oleh kedua media tersebut, beberapa di antaranya menyuarakan mengenai isu gender dan seksualitas. Tagar-tagar tersebuat antara lain \#metoo, \#heforshe, \#womensmarch, dan \#dresslikeawoman.

Gerakan \#metoo merupakan suatu gerakan yang dicetuskan pada tahun 2017 . Tagar ini merupakan kampanye dalam jaringan untuk menggerakan para penyintas pelecehan dan kekerasan seksual baik perempuan maupun laki-laki agar berani bersuara. Dengan adanya gerakan dari para penyintas ini, diharapkan agar pelaku kejahatan seksual dapat terungkap. Gerakan Me Too pertama kali diprakarsai oleh aktivis perempuan Tarana Burke pada tahun 2007. Sepuluh tahun kemudian, gerakan ini muncul kembali karena dipicu oleh dugaan kuat pelecehan seksual di raksasa industri perfilman Amerika Serikat, Hollywood oleh sineas Harvey Weinstein. Aktris Hollywood Alyssa Milano memulai gerakan ini sebagai bentuk solidaritas bahwa masih banyak penyintas kekerasan dan pelecehan seksual yang tidak berani mengungkapkan kisahnya karena berbagai tekanan sosial.

Gerakan kedua adalah \#heforshe yang juga menjadi viral di media-media sosial. Gerakan tagar heforshe bermula dari tulisan aktris yang juga duta Perempuan PBB Emma Watson. Dia tidak sendiri menyebarkan kampanye \#heforshe karena dibantu oleh politikus dan Perdana Menteri Kanada, Justin Trudeau. Gerakan \#heforshe mengajak pengguna internet untuk mewujudkan kesetaraan gender haruslah melibatkan laki-laki. BBC menuliskan beberapa negara seperti Amerika Serikat, Rwanda, Meksiko, dan Republik Demokrasi Kongo kemudian membuat komitmen secara tertulis untuk mewujudkan kesetaraan gender. \#heforshe juga memiliki situs tersendiri yang mengajak untuk terlibat langsung di dalam gerakan tersebut. Situs ini mendorong agar komunitas atau seseorang lebih terbuka dan membuka pikiran serta 
bersifat inklusif terhadap perbedaan.

\#Womensmarch menurut saya adalah salah satu gerakan sosial yang masif baik dari sisi dunia maya dan dunia nyata. Gerakan ini mendorong adanya long march atau pawai tidak hanya di Amerika Serikat (sebagai tempat awal mula gerakan ini) tetapi juga di beberapa kota di Indonesia pada bulan Maret. Ide pawai ini dimulai sejak 21 Januari 2017 lalu dan dilanjutkan 8 Maret tahun 2018 di berbagai negara bersaamaan dengan peringatan Hari Perempuan Internasional.

Gerakan \#womensmarch mengajak semua kalangan dari berbagai gender untuk menyuarakan pendapat mereka terhadap isuisu gender yang tengah menjadi fokus di negara yang mengikuti gerakan ini. Media The New York Times menuliskan Women's March di Amerika Serikat pada 21 Januari 2017 lalu merupakan salah satu bentuk protes setelah pelantikan presiden baru Amerika Serikat, Donald Trump. Gerakan yang bermula dari media sosial Facebook ini kemudian menjadi aksi nyata turun ke jalan sesaat setelah Presiden Trump dilantik. Para pendukung gerakan ini meyakini bahwa Trump merupakan seorang yang misoginis dan masih banyak pekerjaan rumah seperti hak asasi untuk kaum minoritas (kulit berwarna, imigran baru, dan orang beragama Islam) yang terancam akan semakin termarginalkan karena kebijakan-kebijakan
Presiden Trump kelak. Seperti yang dituliskan oleh The New York Times dan dalam situs Women's March sendiri, gerakan ini merupakan suatu peringatan mengenai "perlawanan dini" bahwa kebijakan Presiden Trump yang menyimpang dari hak asasi manusia akan dilawan oleh gerakan massa.

Di Indonesia, Women's March merupakan gerakan yang tidak ada kaitannya dengan politik di Amerika Serikat. Gerakan Women's March di Nusantara fokus pada isu dan permasalahan yang ada di Indonesia dan di kota-kota yang mengadakannya. Di Indonesia Women's March berkampanye untuk menentang kekerasan berbasis gender dengan mendesak disahkannya Rancangan Undang-Undang (RUU) Pekerja Rumah Tangga dan RUU Penghapusan Kekerasan Seksual. Selain itu di kota-kota besar di Indonesia, misalnya Pontianak, Women's March fokus pada kekerasan seksual yang terjadi di ranah domestik seperti kekerasan dalam rumah tangga (KDRT) atau kekerasaan pada saat pacaran. Isu lain yang diusung adalah seruan kepada masyarakat dan pemerintah tentang darurat pernikahan dini yang angkanya semakin tinggi di Indonesia. Pada tahun 2015 berdasarkan data susesnas yang dikutip oleh Tirto.id tercatat bahwa persentase pernikahan dini di Kalimantan termasuk tertinggi di antara provinsi lainta di 
Indonesia. Di Kalimantan Selatan, angka pernikahan dini sebanyak 33,68 persen, pernikahan anak di Kalimantan Tengah sebanyak 33,56 persen, dan di Kalimantan Barat mencapai 32,21 persen.

Di Indonesia, long march Women's March yang diadakan setiap tanggal 8 Maret diikuti oleh kota-kota selain di Jakarta dan Pontianak yaitu Yogyakarta, Kupang, Salatiga, Surabaya, Malang, Ternate, Tondano, Serang, Lampung, Bandung, Sumba, Bali, dan Malang. Selain menyuarakan mengenai kesetaraan gender dan hak-hak perempuan dan anak, Women's March juga menyuarakan marginalisasi komunitas akibat penggusuran lahan maupun perusakan lingkungan.

Gerakan mengenai kesetaraan gender lain yang sempat menjadi viral di media sosial adalah \#dresslikeawoman. Tagar tersebut bermula dari sebuah laporan dari seorang staf kepresidenan Amerika Serikat. Staf tersebut mengatakan bahwa Preseiden Amerika Serikat memintanya untuk berpakaian seperti perempuan. Dari pernyataan tersebut, muncul tagar \#dresslikeawoman beserta foto-foto baik perempuan maupun laki-laki yang tengah bekerja. Tagar tersebut merupakan bentuk sarkasame bahwa pakaian merupakan komoditas yang diberi label gender. Dari hal ini, apabila ada orang yang mengunggah gambar menggunakan \#dresslikeawoman, maka foto tersebut akan memperlihatkan perempuan dengan pakaian terbaik mereka pada saat bekerja entah itu mengenakan celana, rok, atau bahkan pakaian steril yang digunakan untuk operasi.

Gerakan feminisme melalui internet dan media sosial tidak dapat digeneralisir menjadi satu gelombang saja. Gelombang feminismie saat ini telah saling berkelindan antara gelombang pertama hingga gelombang ketiga. Feminisme di Indonesia pada kenyataannya masih berkutat pada kesadaran mengenai mistifikasi ranah domestik dan masih belum tegas untuk melihat bahwa pembagian kerja merupakan konstruksi sosial. Namun, platform Indonesia Feminis dan Laki-laki Baru berupaya memosisikan seluruh gender (tidak hanya laki-laki dan perempuan) menjadi setara dan memiliki hak yang sama.

Sarah Gamble (2006) menuliskan terdapat pendapat bahwa postfeminis ditandai dengan keterlibatan media serta pasar hingga sistem neoliberal di dalamnya. Apabila ditelusur, di balik viralnya sebuah tagar, terselip pula aktor atau artis yang turut menggaungkan isu tersebut. Gamble mengambil dari tulisan Greer (1970) perjuangan perempuan pada postmodern berada di dalam pusaran pasar. Greer menuliskan bahwa terdapat kepercayaan bahwa perempuan yang telah memiliki karir baik, hubungan percintaan yang sempurna, serta dapat membagi perannya di ranah domestik dan publik merupakan salah satu 
"ciri khas" nya. Akan tetapi, seperti yang disebutkan oleh Gamble kemudian bahwa ketika feminisme gelombang kedua muncul pada era modern, feminisme tidak didominasi lagi dari kulit putih.

Ragam feminisme kemudian menyebar dan terungkap satu persatu. Ragam tersebut antara lain adanya "third world feminists" (Gamble, 2006: 43). Feminisme yang semula merupakan gerakan perempuan kulit putih di Eropa dan Amerika Serikat, kini mendapat pertanyaan dari gerakan feminisme dari "kulit berwarna" yang notabene merupakan negara-negara bekas jajahan Eropa. Gamble mengutip bell hooks (1984) bahwa salah satu ciri khas feminis dunia ketiga adalah feminis merupakan bagian dari gaya hidup, bukan sebuah politik.

Feminisme saat ini juga memasuki ranah yang baru yaitu media sosial. Media ini jauh lebih bebas daripada media televisi, koran, atau radio. Dari media sosial, berbagai ideologi dapat beradu pandang tanpa kenal waktu. Meski terkesan “ pindah tempat" akan tetapi saya kira cyberfeminisme dapat menjadi feminis gelombang ketiga karena sangat fleksibel. Melalui media sosial, identitas menjadi kabur atau bahkan menjadi tegas, hal ini tergantung pada seseorang yang menggunakan media sosial tersebut. Gamble menuliskan "it is this combination of commitment with flexibility which is now being claimed by the third wave" (Gamble, 2006: 44).

Kesimpulan: Urgensi Literasi Media Digital Untuk Perkembangan Pembelajaran Gender

Media sosial seperti Indonesia Feminis, Laki-laki Baru, atau Magdelene merupakan salah satu alternatif media dalam memahami gender pada masa kini. Dari berbagai platform media yang muncul di internet mengenai gender baik melalui tagar dan media sosial, salah satu benang merah dari gerakan-gerakan tersebut adalah menuntut kesetaraan gender. Meskipun era telah berubah menjadi era digital saat ini, perjuangan feminisme gelombang pertama yaitu agar haknya dipenuhi oleh konstitusi untuk bersuara di politik, masih tetap diperjuangkan hingga sekarang.

Menurut data yang telah dipaparkan oleh We are Social menunjuukkan bahwa penggunaan internet setiap hari akan bertambah. Dengan berbagai macam platform yang disediakan oleh media sosial, tidak heran apabila dalam waktu yang singkat penggunaan internet akan lebih dari 8 jam dan penggunaan media sosial akan lebih dari 3 jam. Dalam berita yang ditulis oleh CNN Indonesia, media sosial menjadi salah satu tujuan utama ketika seseorang membuka internet. Di dalam media sosial 
konten negatif dan tidak benar (hoax) akan sangat cepat menyebar. $\mathrm{CNN}$ Indonesia mengutip survei yang dilakukan oleh Centre for International Governance Innovation (CIGI) menyatakan bahwa literasi digital di Indonesia sangatlah dibutuhkan saat ini untuk menangkal konten-konten negatif.

Penggunaan media digital sebagai pembelajaran tentu membutuhkan upaya yang panjang. Dalam hal ini literasi digital merupakan salah satu cara terutama untuk memanfaatkan informasi dari media sosial. Menurut Douglas A.J Belshaw yang dikutip oleh Tim Penyusun Materi Pendukung Literasi Digital, Kementerian Pendidikan dan Kebudayaan, 2017 menyatakan bahwa pengembangan literasi digital memerluka delapan hal dasar yaitu:

a. Kultural; memahami konteks pemanfaatan digital

b. Kognitif; pemahaman ketika menilai suatu konten

c. Konstruktif; pemikiran yang mereka ulang suatu informasi yang aktual

d. Komunikatif; membuka diri dan pikiran dalam jejarin serta komunikasi dengan pihak lain

e. Kepercayaan diri untuk bertanggung jawab

f. Kreatif; menemukan hal-hal baru

g. Kritis terhadap konten berita

h. Tanggung jawab sosial.

Belshaw menyatakan bahwa pemahaman mengenai konteks terhadap konten berita atau informasi dalam media sosial dan internet sangat penting. Literasi digital tidak hanya menuntut seorang pengguna internet memahamai perangkat komputernya atau telepon pintarnya, akan tetapi cakap dalam menyaring informasi secara cerdas dan cermat untuk membina komunikasi dalam kehidupan sosial (Belshaw, 2011 dalam Materi Pendukung Literasi Digital, Kementerian Pendidikan dan Kebudayaan, 2017: 8). Literasi media digital diperlukan untuk memahami konteks serta bersofat kritis terhadap media tersebut. Selain itu, pemahaman media digital juga meningkatkan keterampilan untuk navigasi pencarian informasi (McPherson, dkk, 2008).

Dalam memahami paradigma feminisme salah satunya adalah kesetaraan gender, media sosial memang menjadi salah satu alternatif untuk membuka jalan terhadap informasi yang lainnya. Akan tetapi, literasi digital harus pula berimbang dengan pembacaan sejarah mengenai feminisme dan kesetaraan gender itu sendiri. Konten-konten dalam Laki-laki Baru dan Indonesia Feminis merupakan representasi pembahasan sederhana mengenai perdebatan panjang dalam kesetaraan gender. Media sosial menjadi tempat yang murah dan cepat dalam pembahasan isu ini. Meski demikian, tidak sedikit pula saya temukan komentarkomentar negatif di internet mengenai 
gerakan sosial yang diusung oleh ketiga platform media sosial tersebut.

Ujaran kebencian atau komentar negatif mengenai perjuangan dalam menumbuhkan kesadaran kesetaraan gender, menunjukkan bahwa budaya patriarki masih kuat mengakar meskipun era telah berganti. Hingga saat ini, para aktivis perempuan masih memperjuangkan kesetaraan di dalam ranah domestik dan publik, hak untuk memilih atau dipilih di dalam politik, atau mengenai pengungkapan identitas gender. Dari hal ini, dapat disimpulkan bahwa pergerakan feminisme meski sudah melangkah pada era digital, tetap saja mengulang perjuangan dari feminisme gelombang pertama. Media sosial menjadi alternatif dan awalan yang baik agar pemahaman mengenai gender dapat tersebar luas dengan cepat. Konsekuensinya, penyedia platform sebaiknya memberikan sejarah atau menyediakan literasi untuk dibaca. Selain itu, pengguna media sosial juga wajib membekali diri mengenai literasi yang berkaitan dengan isu-isu yang disediakan oleh suatu platform.

\section{Daftar Pustaka}

Bray, Fransesca. (2007). "Gender and Technology" dalam Annual Review of Anthropology, Vol. 36 (2007)hal. 37-53. Dipublikasikan oleh Annual Reviews. http://www.jstor.org/stable/25064943 [Diakses pada 21/04/2018]

Dobson, Amy Shields. (2015). Postfeminist Digital Cultures: Femininity, Social Media and SelfRepresentation. New York: Palgrave MacMillan.

Everett, Anna. (2004). "Cyberfeminism and Cyberwomanism: High-Tech Mediations of Feminism's Discontents" dalam Signs, Vol.30, No.1, Hal. 1278-1286 Beyond the Gaze: Recent Approaches to Film Feminism Special Issue. Published: The University of Chicago Press. http://www.jstor.org/stable/10.1086/422235 [Diakses pada 16/05/2018].

Gamble, Sarah. (2006). Feminism and Postfeminism. London: Routledge.

Genz, Stephanie dan Benjamin A. Barbon. (2009). Postfeminism: Cultural Texts and Theories. Edinburgh: Edinburgh University Press.

Keller, Jessalynn. (2016). "Making Activism Accessible: Exploring Girl's Blogs as Sites of Contemporary Feminist Activism" dalam buku Girlhood and the Politics of Place (Ed. Claudia Mitchell dan Carrie Rentschler). Dipublikasikan oleh Berghahn Books. http://www.jstor.org/stable/j.ctt14jxn16.20 [Diakses pada 17/05/2018].

Livingstone, Sonia. (2008). "Internet Literacy: Young People's Negotiation of New Online Opportunities" dalam Digital Youth, Innovation, and the Unecpected (Ed. Tara McPherson, dkk). Massachusetts: The MIT Press.

McPherson, Tara, The John D, dan Catherine T.MacArthur Foundation (ed.). (2008). Digital Youth, Innovation, and the Unexpected. Massachusetts: The MIT Press.

Porta, Donatella Della dan Mario Diani. (2006). Social Movements: An Introduction. Oxford: 
Blackwell Publishing.

Stivens, Maila.(2005). "Gender, Rights, and Cosmopolitanisms" dalam Anthropology and the New Cosmopolitanism Ed. Pnina Werbner, 2005. New York: Berg.

Thornham, Sue. (2001). "Second Wave Feminism" dalam Feminism and Postfeminism (Ed. Sarah Gamble). Hal.25-35. London: Routledge.

Tim Penyusun Materi Pendukung Gerakan Literasi Nasional. (2017). Kementerian Pendidikan dan Kebudayaan: Jakarta. [ Materi dapat diunduh di http://gln.kemdikbud.go.id/glnsite/buku]

Wajcman, Judy. (1991). Feminism Confronts Technology. Pernnsylavia: Pennsylvania StateUniversity Press.

\section{Media Dalam Jaringan}

http://kbbi.kemdikbud.go.id/entri/viral

https://wearesocial.com/uk/blog/2018/01/global-digital-report-2018

https://wearesocial.com/uk/blog/2018/01/global-digital-report-2018

https://tirto.id/profil-konsumen-belanja-online-di-indonesia-cuEG

https://www.globalcitizen.org/en/content/hashtag-activism-hashtag10-twitter-trends-dresslik/

https://www.bbc.com/news/world-42251490

http://www.heforshe.org/en

https://www.womensmarch.com/march/

https://www.nytimes.com/2017/01/21/us/womens-march.html

https://tirto.id/pernikahan-anak-merenggut-hak-anak-dan-merugikan-negara-cJiQ

https://www.cnnindonesia.com/teknologi/20171218192500-192-263281/pengguna-internet-di-indonesia-

akses-medsos-3-jam-per-hari

https://www.instagram.com/indonesiafeminis/?hl=en

https://web.facebook.com/indonesiafeminis/?_rdc=1\&_rdr

https://lakilakibaru.or.id/

https://lakilakibaru.or.id/pelecehan-seksual-itu-ada-dan-nyata/

https://lakilakibaru.or.id/umar-badrun-islam-berbagi-peran-domestik-adalah-tanggung-jawab-keluarga/

https://www.instagram.com/womensmarchjkt/?hl=en 